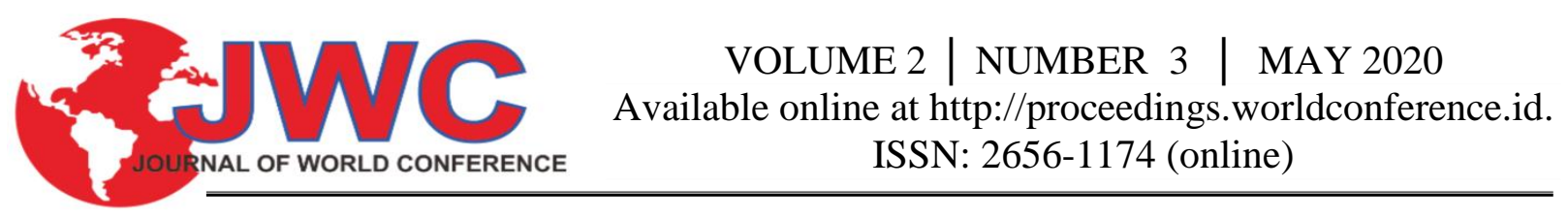

\title{
Analysis of Bicycle Path Infrastructure in Jakarta to Improve Cycling Comfort
}

\author{
Sunandar Ali dan Rahma Waldhani Tia \\ Lecturer, Faculty of Engineering, Mercu Buana University, Indonesia, \\ ali.sunandar@gmail.com, tiarahma88@gmail.com
}

\begin{abstract}
The Provincial Government of DKI Jakarta is demanded to provide infrastructure and infrastructure that is environmentally friendly. one of the steps of the DKI Jakarta provincial government is to build bicycle lane infrastructure. Previously, the Government had built bicycle path infrastructure but it was not used as it functions. The purpose of this study is to determine the variables that most affect the infrastructure of the bicycle lane and provide suggestions for managing the variables that most influence so that bicycle lane users get the comfort of cycling so that the infrastructure is used properly and can reduce the level of air pollution in Jakarta. In this study, the authors used a quantitative research method by distributing questionnaires to respondents of active cyclists and passive cyclists. The questionnaire distributed contained variables of infrastructure facilities and infrastructure, and then the results of the questionnaire data which were primary data were processed using the Statistical Application Program. This research uses 4 stages of the questionnaire by using validity, reliability, descriptive test, Spearman correlation rank test, and regression test. The results of this study are the Bicycle Path Infrastructure in Jakarta has 3 variables that most influence in increasing the comfort of cyclists, there is the Evenness of the Path $(49,4 \%)$, The Limiting of the Lane (33\%), and the Existence of Markers(17.1\%).
\end{abstract}

\section{Keywords}

Jakarta, Infrastructure, Bicycle Path, Dominant Variables.

\section{Introduction}

In addition to pollution, one of the other transportation problems is the first-mile last mile, which is the journey from the home starting point to public transportation to the final destination point. First mile last mile in Jakarta is still a mess where Jakarta people prefer motorized vehicles as transportation to take them to the final destination or from the starting point of the house to public transportation. This is a problem because the increase in motor vehicles also has an impact on increasing pollution in Jakarta. Therefore, the Provincial Government of DKI Jakarta provides infrastructure and facilities that are environmentally friendly. One of the steps of the DKI Jakarta provincial government is to build bicycle path infrastructure.

One of the existing bicycle lanes in Jakarta is the bicycle lane on Jl. Melawai, South Jakarta. The bike path that was first ratified in 2011 connects the Ayodya Park area with the office of the Mayor of South Jakarta. Start from Ayodya Park, the bicycle path leads to Blok M MRT station via Jalan Melawai Raya. After that, the bicycle path crosses Plaza M Block and Melawai Plaza. Then, the bicycle lane turns right through the Iskandarsyah Raya road to the South Jakarta Mayor's Office.
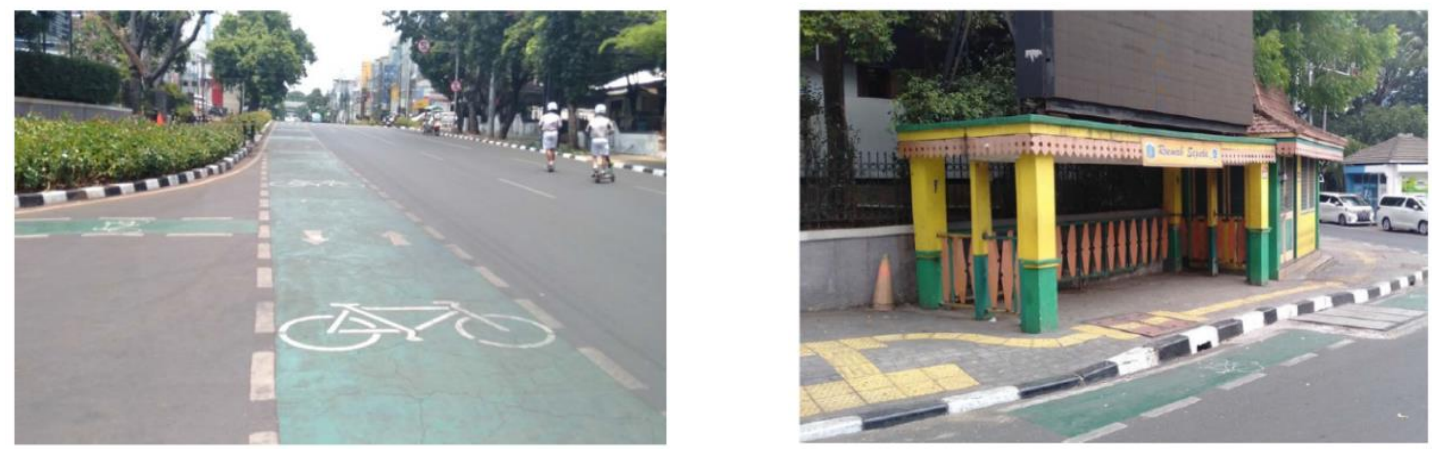

Source: Walda Marison "Jalur Sepeda di Jakarta Selatan, dari Taman Ayodya hingga Kantor Walikota”, 2019 Figure 1. Bicycle Path in South Jakarta 


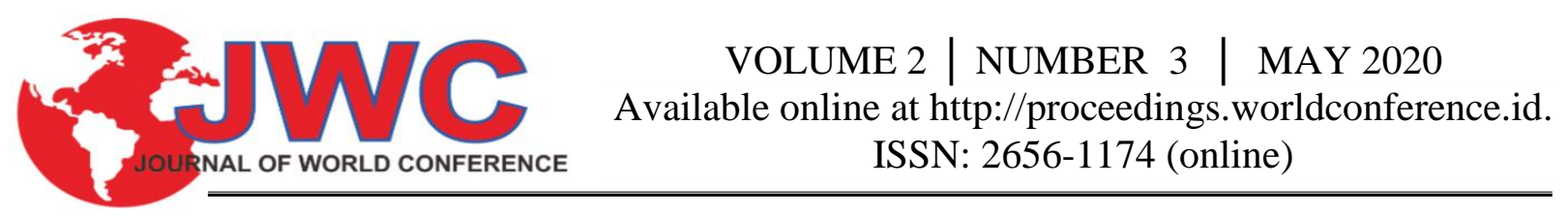

The infrastructure of the bicycle lane must be supported in order to make the bike lane users comfortable. Facilities and infrastructure are tools that support the success of a process so that it is carried out in public services, because if these two things are not available then all activities carried out will not be able to achieve the expected results according to plan.

Based on the problems that occur above, it is necessary to do an analysis to determine the infrastructure of bicycle lanes in Jakarta that can improve the convenience of bicycle lane users.

\subsection{Problem Formulation}

Based on the background stated earlier, the main issues in the study are:

a. What are the dominant variables on the bicycle lane infrastructure which are influences to increase the convenience of bicycle lane users?

b. What is the strategy for managing the bicycle path infrastructure?

\subsection{Research Objectives}

The purpose of this research is:

a. To find out the dominant variable in the bicycle lane infrastructure that has an effect on increasing the convenience of bicycle lane users.

b. To find out the strategy of managing bicycle path infrastructure

\section{Literature Review}

A bicycle lane is a lane specifically designated for bicycle user traffic and non-motorized vehicles that require human labor, separated from motorized vehicle traffic to improve the safety of bicycle user traffic. The use of bicycles indeed needs to be given more facilities to improve the safety of bicycle users.

\subsection{Types of Special Lane Bicycles}

In principle, the bicycle network must be designed to connect the origin and destination of the trip by passing the existing obstacles. All roads must be considered bicycle use unless explicitly prohibited. The bicycle path must be a network to ensure that cyclists can safely access all destinations. In general there are three types of bicycle lanes, there are.

\subsubsection{Bike Path}

This lane is completely separate from the road and is often integrated with pedestrian facilities. Intersection with the highway usually occurs Bike Path must cut the road or intersection. This lane offers the best service because it is safe, safe, and free of pollution. Bike Path was created for example Cyclo Ruttas in Bogota, by designing bicycle lanes that have a completely different lane than motorized vehicle lanes.

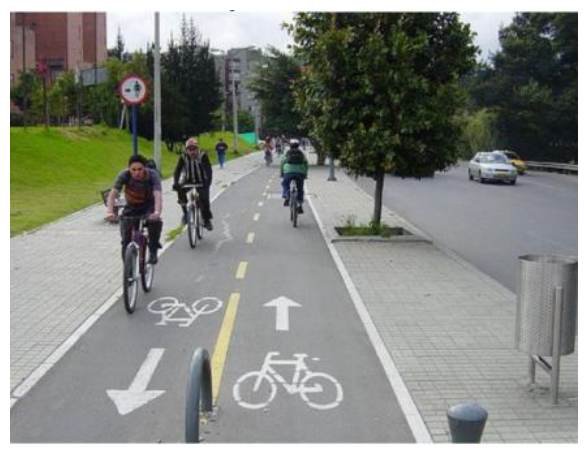

Source : Raden Pintyo, 2015

Figure 2. Bike Path

\subsubsection{Bike Lane}

The bicycle lane is part of a road marked with markers for cyclist use. Usually made in the direction of the motor vehicle lane flow. Although it can also be designed to go both ways on one side of the road. Bicycle lanes are separated by an unbroken line on the road section and separated by a broken line in the area approaching the intersection, which indicates that motor vehicle and bicycle users are turning lanes to turn. 

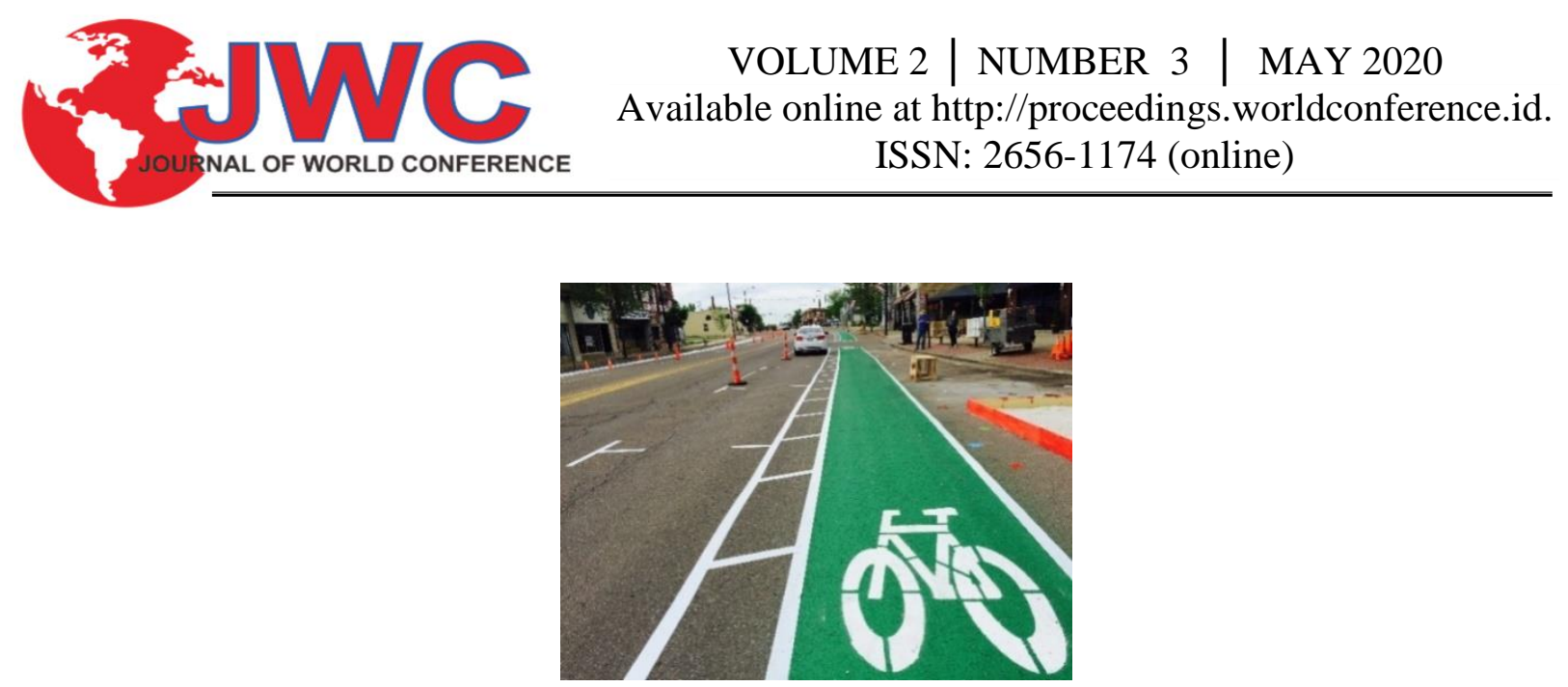

Source : Raden Pintyo, 2015

Figure 3. Bike Lane

\subsubsection{Bike Route}

Bicycle routes are designed to be shared between motorized and bicycle traffic. This design is usually suitable for lanes with speeds less than $40 \mathrm{~km} / \mathrm{h}$ with a vehicle volume of less than 3000 vehicles/day.

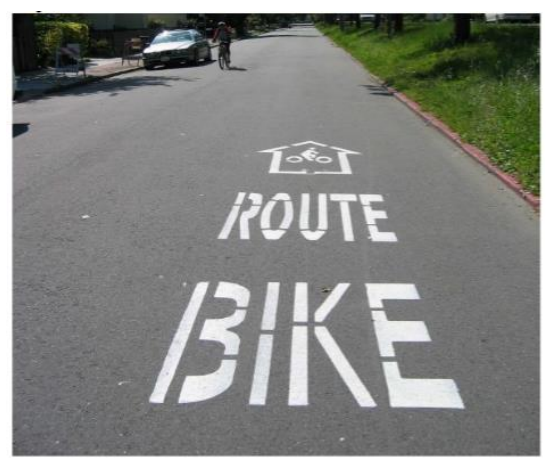

Source : Raden Pintyo, 2015 Figure 4. Bike Route

Figure 4. Bike Route

\subsection{Bicycle Path Infrastructure}

Infrastructure or infrastructure is a place for the needs or places of movement of facilities that are equipped with other supporting facilities available or placed in a place or also with the term permanent way or fixed installation. Road infrastructure consists of 3 elements, namely roads, terminals and other equipment. Bicycle users must also be given facilities to improve the safety of bicycle users and can increase the speed of traffic for bicycle users. The following market facilities must be in the bicycle lane [3]:

\subsubsection{Signs and Road Markings}

Signage for bicycle lanes is also needed to increase cyclist safety. The London Cycling Design Standard divides the signposts and road markings into 3 sections, there are [4]:

1) Regulatory, regulations regarding traffic management that can be implemented;

2) Warning and informatory, signposts and road markings that warn of danger and lead to the correct position;

3) Route guidance, a signboard for directions and location

\subsubsection{Lighting}

Lighting should also be considered to facilitate bicycle lanes at night. Lighting can help to minimize conflicts between bicycles and motorized vehicles at a crossroads. Lighting provides comfort by lighting up the bicycle lane so that the bike can see the path, conditions and obstacles [5]. 


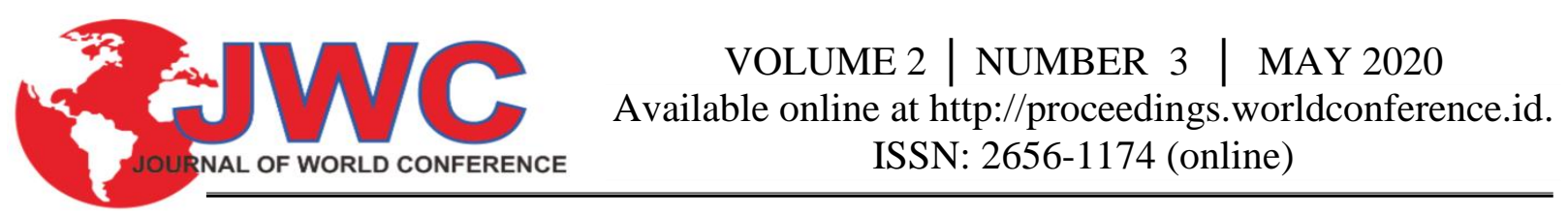

\subsubsection{Parking lot}

Parking space is one of the determinants of cyclist comfort. Parking lots must be considered in infrastructure in the bicycle lane. A less secure parking lot can make a cyclist lazy to ride a bicycle. Bicycle rack is a safe bicycle parking area and can be installed in various locations. The bicycle rack must be able to support the bicycle with a frame that is upright in two places to prevent the bike from falling and allow the bicycle frame and one or two bicycle wheels to be locked [6].

\subsubsection{Limiting Path / Protection Element}

There are 3 protection designs for bicycle lanes namely [7]:

1) Road segment with continuous curb, ie protection with continuous separator.

2) Road segment with setback parking, which is continuous protection by allowing access in and out of buildings.

3) Road segment with limited space, namely with paint color to increase the attention of other road users towards cyclists.

\subsubsection{Crossing the Bicycle Path}

Some of the principles used in designing bicycle crossing are as follows [3]:

1) Modification of existing intersections, i.e. modifying existing intersections both physically (geometrically) and by regulation of signals, signs and markers for bicycle crossing traffic.

2) Crossing the road section, which is a bicycle crossing in the middle of the road section.

3) Signaling, signs and markings can be in the form of separate bicycle crossings or combined with pedestrian crossings for urban roads with heavy traffic, crossings can be designed not on a level with underpass or overpass construction.

\subsection{Reference on Planning a Bicycle Path in Indonesia}

Every road used for public traffic must be equipped with road equipment in the form of [7]:

a. Traffic signs

b. Road markings

c. Traffic Signaling Tool

d. Street Lighting Equipment

e. Roadway Safety and Control Devices

f. Road Safety and Monitoring Equipment

g. Facilities for Bicycles, Pedestrians and Disabled, and

h. Facilities that support traffic activities and road transportation that are on the road and outside the road body.

\subsection{References to Planning a Bicycle Path based on the London Cycling Design Standard}

Bicycle trails and trails are an important part of all traffic management tools. This must be able to:

a. Provides safety and comfort benefits based on the level of separation from the motor traffic provided and the surface quality of the bikes.

b. Allocate space for biking

c. Provides recommended route information for cyclists

d. Increasing bicycle awareness as a serious mode of transportation and thus encouraging more people to ride bikes. 


\section{Research Methodology}

To achieve this research objective, the study is divided into several stages, including:

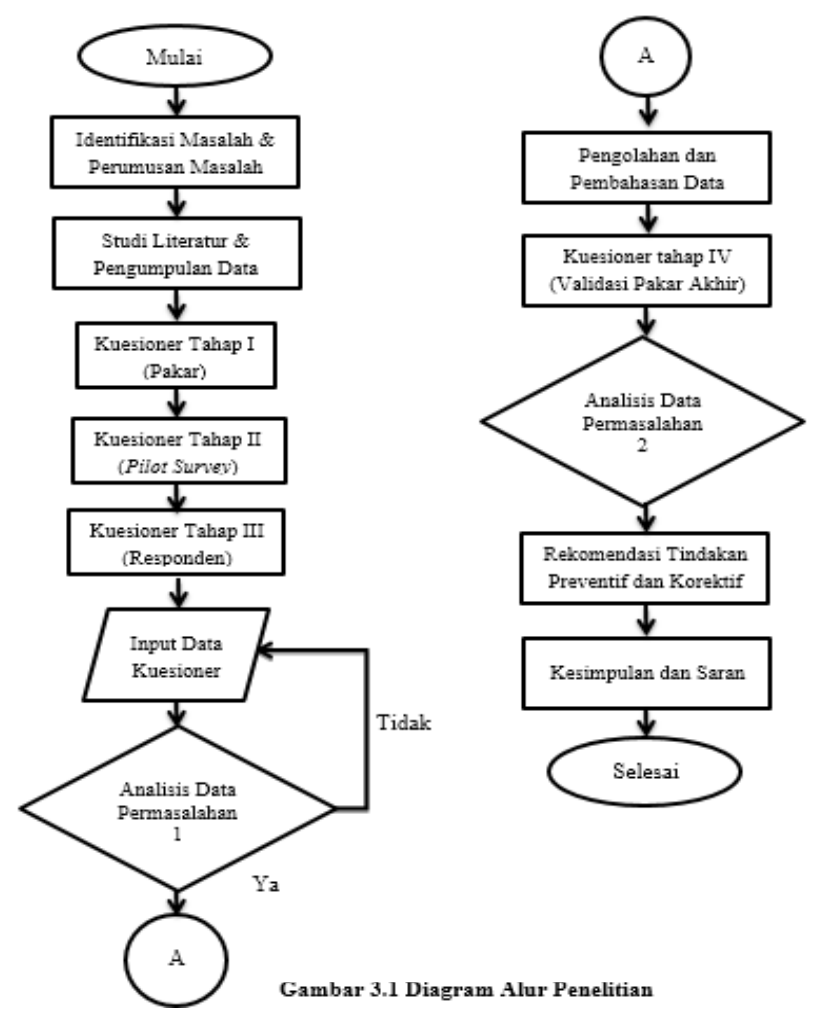

Source: Researcher's Processed Data, 2019

Figure 5. Flowchart of research

The method used in this research is data collection through a questionnaire distributed to several respondents. The analytical method used is descriptive quantitative. A quantitative approach is research that focuses on testing hypotheses, the data used must be measurable, and produce conclusions that can be generalized. This approach uses inferential statistical (analytical tool) methods. This analytical method aims to describe the public response to bicycle lane infrastructure in DKI Jakarta. In addition quantitative descriptive analysis is used to obtain information about the perception of bicycle users.

Expert Criteria:

a. Expert in Infrastructure, and / or representation in Government.

b. Minimum education of $\mathrm{S} 1$ or $\mathrm{S} 2$.

c. Minimum 25 years experience for S1 and minimum 10 years for S2.

Respondent criteria:

a. Minimum age of 24 years.

b. Minimum education of S1.

c. Minimum 2 years work experience.

\subsection{Research variable}

In this study the independent variable used is known as $(\mathrm{X})$ is a variable that is Bicycle Path Infrastructure in Jakarta, while the dependent variable (Y) is the convenience of bicycle users.. 
Table 1. Research variable

\begin{tabular}{ccc}
\hline VARIABEL & Deskripsi & Referensi \\
\hline X1 & width of the bicycle lane & Pipit, et al,. 2015 \\
X2 & the length of the bicycle path & Pipit, et al,. 2015 \\
X3 & pavement pathway & Raden Pintyo, et al., 2015 \\
X4 & flatness of the bicycle lane & Ichda Maulidya, et al.,2016 \\
X5 & heavy climbs & Raden Pintyo, et al., 2015 \\
X6 & mild incline & Raden Pintyo, et al., 2015 \\
X7 & light derivative & Raden Pintyo, et al., 2015 \\
X8 & sharp derivative & Raden Pintyo, et al., 2015 \\
X9 & path type & Sharinatol, et al.,2019 \\
X10 & Mileage Cycle & Pipit, et al,. 2015 \\
X11 & Cycling Time & Pipit, et al,. 2015 \\
X12 & Cycling routine per week & Pipit, et al,. 2015 \\
X13 & Traffic volume & Ichda Maulidya, et al.,2016 \\
X14 & Road Capacity & Ichda Maulidya, et al.,2016 \\
X15 & Group cyclists & Pipit, et al,. 2015 \\
X16 & Cyclists Do Not Carry Goods & Pipit, et al,. 2015 \\
X17 & Cyclists Carry Goods & Pipit, et al,. 2015 \\
X18 & Traffic Light & Sharinatol, et al.,2019 \\
X19 & Road markings & PP No.79 th. 2013 \\
X20 & Connectivity & Angela Hull, et al., 2014 \\
X21 & Limiting the Bicycle Path & Angela Hull, et al., 2014 \\
X22 & Lighting & PP No.79 th. 2013 \\
X23 & Road shade / barrier & Angela Hull, et al., 2014 \\
X24 & Traffic Signaling Tool & PP No.79 th. 2013 \\
X25 & Road Safety and Monitoring Equipment & PP No.79 th. 2013 \\
X26 & Bicycle parking & Bambang Tripoli, et al., 2018 \\
X27 & Bicycle Rack & Bambang Tripoli, et al., 2018 \\
X28 & Braffic Light waiting room & Bambang Tripoli, et al., 2018 \\
X29 & Band use characteristics & Bambang Tripoli, et al., 2018 \\
X30 & Source: Researcher's Processed Data, 2019 & \\
& & \\
& &
\end{tabular}

\subsection{Measurement Scale}

Measurement scale is an instrument or tool that requires researchers to assign subjects to categories by assigning numbers or numbers to these categories (Tampubolon, 2018). The scale criteria used by the author in assessing bicycle lane infrastructure towards the convenience of lane users in the questionnaire in this study using a Likert Scale.

Table 2. Measurement Scale

\begin{tabular}{cc}
\hline Groups & Pre-Test \\
\hline Sangat Tidak Berpengaruh & 1 \\
Tidak Berpengaruh & 2 \\
Cukup Berpengaruh & 3 \\
Berpengaruh & 4 \\
Sangat Berpengaruh & 5 \\
\hline Source: Researcher's Processed Data, 2019
\end{tabular}




\section{Analysis and Results}

The data collection consisted of four stages that began with the distribution of questionnaires to several experts, followed by the distribution of pilot survey questionnaires, then the distribution of questionnaires to respondents and finally the validation of the final stage experts to validate the bicycle path infrastructure strategy. Of the 35 variables validated by experts, filtered to 30 variables to be analyzed.

\subsection{Validity and Reliability Results}

For reliability testing, the Cronbach's alpha method is used where the value must be greater than 0.6 for each variable and 0.8 for the entire variable to be considered reliable. Based on the reliability test results obtained show that all variable items in the study can be declared reliable and have a high level of reliability.

Table 3. Validity and Reliability Results

\begin{tabular}{|c|c|}
\hline Cronbach's Alpha & $\mathrm{N}$ of Items \\
\hline .856 & 31 \\
\hline
\end{tabular}

\subsection{Spearman Rank Correlation Results}

The Spearman Rank Test is used to see whether the relationship is significant or not, by referring to the column correlation coefficient (rcount) compared to the rtable value. The table value is .1654. for statistical decision making is a variable that has a correlation coefficient> .1654

Table 4. Correlation of Relationship of Variables X and Y

\begin{tabular}{cccc}
\hline VARIABEL & $\mathrm{N}$ & Correlation Coefficient & Sig. (2-tailed) \\
\hline $\mathrm{X} 1$ & 100 & $.387^{* *}$ & .000 \\
$\mathrm{X} 2$ & 100 & -0.036 & .719 \\
$\mathrm{X} 3$ & 100 & $.421^{* *}$ & .000 \\
$\mathrm{X} 4$ & 100 & $.593^{* *}$ & .000 \\
$\mathrm{X} 5$ & 100 & 0.037 & .714 \\
X6 & 100 & 0.011 & .913 \\
X7 & 100 & 0.087 & .388 \\
$\mathrm{X} 8$ & 100 & -0.094 & .352 \\
X9 & 100 & $.451^{* *}$ & .000 \\
X10 & 100 & -0.038 & .707 \\
X11 & 100 & -0.045 & .657 \\
X12 & 100 & 0.016 & .871 \\
X13 & 100 & $.403^{* * *}$ & .000 \\
X14 & 100 & $.313^{* *}$ & .002 \\
X15 & 100 & -0.039 & .702 \\
X16 & 100 & -0.018 & .857 \\
X17 & 100 & 0.036 & .722 \\
X18 & 100 & $.358^{* *}$ & .000 \\
X19 & 100 & $.531^{* *}$ & .000 \\
X20 & 100 & $.395^{* *}$ & .000 \\
X21 & 100 & $.528^{* *}$ & .000 \\
X22 & 100 & $.371^{* *}$ & .000 \\
X23 & 100 & $.341^{* *}$ & .001 \\
X24 & 100 & $.240^{*}$ & .016 \\
X26 & 100 & $.410^{* *}$ & .000 \\
X27 & 100 & -0.076 & .455 \\
X28 & 100 & 0.002 & .983 \\
& & &
\end{tabular}




\begin{tabular}{cccc} 
X29 & 100 & -.004 & .967 \\
X30 & 100 & .012 & .909 \\
\hline \multicolumn{4}{c}{ Source: Processed Data Processing Statistics Program (2019) }
\end{tabular}

From table 4 above, it can be concluded that the variables which are stated to have a strong correlation level are X1, X3, X4, X9, X13, X14, X18, X19, X20, X21, X22, X23, X24, X26.

\subsection{Regression Analysis Results}

The relationship model between pineapple variables (bicycle lane infrastructure) to the dependent variable (cyclist comfort) is studied by regression analysis using statistical processing programs. The input for this regression analysis are the dominant factors in the infrastructure of the bicycle lane to the comfort of the cyclist that has been analyzed for factors. Following are the outputs of the regression analysis.

Table 5. Model Summary

\begin{tabular}{ccccc}
\hline Model & $\boldsymbol{R}$ & $\boldsymbol{R}$ Square & $\begin{array}{c}\text { Adjusted } \boldsymbol{R} \\
\text { Square }\end{array}$ & $\begin{array}{c}\text { Std. Error of the } \\
\text { Estimate }\end{array}$ \\
\hline 1 & $.661^{\mathrm{a}}$ & .436 & .431 & .532 \\
2 & $.769^{\mathrm{b}}$ & .591 & .583 & .455 \\
3 & $.799^{\mathrm{c}}$ & .638 & .627 & .431 \\
\hline \multicolumn{4}{c}{ Source: Processed Data Processing Statistics Program (2019) }
\end{tabular}

The model which has the highest $\mathrm{R}$ square value is model 3. The correlation / relationship value (R) is equal to .799 and the magnitude of the influence of the independent variable on the dependent variable is called the coefficient of determination (R2) of .638, meaning the effect of the variable free to the dependent variable is $63.8 \%$, while the rest is influenced by other variables.

Table 6. Coefficients dan T tests

\begin{tabular}{|c|c|c|c|c|c|c|}
\hline & \multirow[t]{2}{*}{ Model } & \multicolumn{2}{|c|}{$\begin{array}{c}\text { Unstandardized } \\
\text { Coefficients } \\
\end{array}$} & \multirow{2}{*}{$\begin{array}{c}\begin{array}{c}\text { Standardized } \\
\text { Coefficients }\end{array} \\
\text { Beta }\end{array}$} & \multirow[t]{2}{*}{$\mathbf{t}$} & \multirow[t]{2}{*}{ Sig. } \\
\hline & & B & $\begin{array}{l}\text { Std. } \\
\text { Error }\end{array}$ & & & \\
\hline \multirow{2}{*}{1} & (Constant) & 1.211 & .350 & & 3.466 & .001 \\
\hline & $\mathrm{x} 4$ & .690 & .079 & .661 & 8.709 & .000 \\
\hline \multirow{3}{*}{2} & (Constant) & .290 & .335 & & .864 & .390 \\
\hline & $\mathrm{x} 4$ & .531 & .073 & .508 & 7.304 & .000 \\
\hline & $\mathrm{x} 21$ & .391 & .064 & .422 & 6.068 & .000 \\
\hline \multirow{4}{*}{3} & (Constant) & .041 & .325 & & .127 & .899 \\
\hline & $\mathrm{x} 4$ & .494 & .070 & .473 & 7.099 & .000 \\
\hline & $\mathrm{x} 21$ & .330 & .063 & .356 & 5.195 & .000 \\
\hline & $\mathrm{x} 19$ & .171 & .049 & .232 & 3.511 & .001 \\
\hline
\end{tabular}

Source: Processed Data Processing Statistics Program (2019)

so the equation can be written as follows:

$\mathrm{Y}=0.41+0.494 \mathrm{X} 4+0.330 \mathrm{X} 21+0.171 \mathrm{X} 19$

Information :

$\mathrm{Y}=$ Cycle Comfort

X4 = Path Flatness Variable

X21 = Variable Presence of Path Limits 
X19 = Variable Presence of Path Markings

So it can be translated as follows:

1. The 0.410 constant states that if there is no value for each factor, the $\mathrm{Y}$ value is 0.410

2. The regression coefficient $\mathrm{X} 4$ of 0.494 states that for each addition of 1 value of the variable $\mathrm{X} 4$, the value of $\mathrm{Y}$ increases by 0.494 . Then the comfort level of cyclists rises by $49.4 \%$ if the bike lane is level.

3. X21 regression coefficient of 0.330 states that each addition of 1 value of the variable $\mathrm{X} 21$, then the value of Y increases by 0.330 . Then the comfort level of cyclists rises by $33 \%$ if there are bicycle lanes with vehicle lanes.

4. X19 regression coefficient of 0.171 states that for each addition of 1 value of the variable X19, the value of Y increases by 0.171 . Then the comfort level of cyclists rises by $17.1 \%$ if there are bicycle lane markers.

\section{Hypothesis}

from the results of the above output we can know the significance value of $0.000<0.005$, then $\mathrm{H} 0$ is rejected and $\mathrm{H} 1$ is accepted. Ho's statement is that if no bicycle lane repairs / upgrades are made then the lane user is uncomfortable, it is rejected. Whereas the $\mathrm{H} 1$ statement is that if improvements / improvements to the bicycle lane infrastructure are made, the convenience of the participants will be increased, which is accepted, which means there is a significant (significant) variable (X4, X21, and X19) influence on the $\mathrm{Y}$ variable.

\section{Conclusions}

Based on the analysis described and the results that have been obtained, it can be concluded that there are 3 dominant variables that affect cyclist comfort. The following dominant variables and handling / strategy for each variable:

1. Dominant variables on bicycle lane infrastructure in Jakarta that have an influence on the comfort of bicycle lane users, namely, X4: Evenness of the Bicycle Path, X21: The existence of a Bicycle Path Restrictor, and X19: Bicycle Path Markings.

2. Strategy on variables that influence the following

$\mathrm{X} 4$ : Flatness of the Bicycle Path

a. Cause: Evenness of the path is still lacking, the road is bumpy / pitted.

b. Impact: Cyclists feel uncomfortable and safe using the Bicycle Path

c. Preventive Measures: Perform maintenance on bumpy and uneven paths

d. Corrective Action: Make improvements on the path that is hollow / wavy

X19 : Bicycle Lane Markings

a. Cause: Bike Path Markings are minimal Information and not visible

b. Impact: Cyclists rarely use the Bicycle Path for Cycling

c. Preventive Measures: Clarify Bicycle Lane Markings, Perform Maintenance on existing facilities and infrastructure

d. Corrective Action: Procurement / installation and increase bicycle lane markings

$\mathrm{X} 21$ : There is a Bicycle Path Restrictor

a. Cause: Limiting the path that is less appropriate / considered less safe

b. Impact: Cyclists feel uncomfortable and safe using the Bicycle PathPreventive Measures: Perform Maintenance on existing facilities and infrastructure elements, Clarify Bicycle Path Limits

c. Corrective Action: Conduct selection / installation of safe lane barriers for cyclists.

\section{Suggestion}

1. Based on the results obtained, there are several infrastructure facilities that affect the comfort, therefore it is recommended to improve facilities and infrastructure for smooth and increasing bicycle lane users.

2. This study reviews the factors that influence the structure of bicycle lanes in Jakarta for the convenience of cyclists. Further research can be continued regarding the analysis of lane user satisfaction with facilities and infrastructure on the speda lane in Jakarta and also on the analysis of the assessment of facilities. 


\section{References}

Priambodo, Raden Pintyo Pratomo, Sutomo Kahar, Haniah, (2015). Pembuatan Peta Jalur Kondusif Kota Semarang. Semarang: Universitas Diponegoro.

Anonim, (1992). Standar Geometrik Jalan. Jakarta: Peraturan Pemerintahan Pekerjaan Umum

Tripoli, Bambang, Rahmat Djamaludin, Jalil Amin., (2018). Efektifitas Kinerja Jalur Sepeda di Kawasan Kota Meulaboh. Aceh: Universitas Teuku Umar.

Anonim, (2014). London Cycling Design Standar. London: Transport For London.

Anonim, (2018). Caltrans Highway Design Manual. California: STATE OF CALIFORNIA DEPARTMENT OF TRANSPORTATION

Anonim, (2019). Laporan Workshop Percepatan Jakarta Ramah Bersepeda. Jakarta: Institute for Tansportation and Development Policy.

Anonim, (2013). Peraturan Pemerintah Republik Indonesia Nomor 79. Jaringan Lalu lintas an Angkutan Jalan. 